\title{
TANAH TERLANTAR, MENYALAHI FUNGSI SOSIAL TANAH
}

\author{
Yuwono*
}

\begin{abstract}
Abstrak
Undang-undang Dasar 1945 BAB XIV pasal 33 ayat (3) mengamanahkan bahwa bumi dan air dan kekayaan alam yang terkandung di dalamnya dikuasai oleh negara dan dipergunakan untuk sebesar-besarnya kemakmuran rakyat.

Tanah, yang merupakan tempat pijakan sekaligus tempat untuk tinggal dan dapat juga digunakan untuk berusaha, sering dimiliki secara berlebih (posesif ) oleh orang perorang atau suatu badan.

Hal tersebut tidaklah terlalu salah, namun ironisnya, terkadang melupakan kewajiban terhadap tanah tersebut dan fungsi dari tanah tersebut. Kewajibannya adalah membayar pajak terhadap tanah tersebut ( $P B B=P a j a k$ Bumi dan Bangunan) dan fungsi tanah tersbut sebagai fungsi sosial dari tanah tersebut.

Pada setiap bidang tanah akan melekat suatu hak, hak ini merupakan suatu bukti kuat terhadap kepemilikan bidang tersebut. Contoh hak atas tanah adalah hak milik, hak guna bangunan, hak pakai dan sebagainya.

Walaupun kepemilikan tanah telah jelas, namun tanah tidak boleh ditelantarkan, misalnya Tanah Hak Milik, Hak Guna Usaha, Hak Guna Bangunan ataupun Hak Pakai. Tanah dapat dinyatakan sebagai tanah terlantar apabila tanah tersebut dengan sengaja tidak dipergunakan oleh pemegang haknya sesuai dengan keadaannya atau sifat dan tujuan haknya atau tidak dipelihara dengan baik. , karena jika tanah ditelantarkan, maka tanah tersebut akan dikuasai langsung oleh negara.
\end{abstract}

Kata Kunci: Fungsi sosial tanah, tanah telantar, dan kewenangan negara terhadap tanah telantar.

Tanah yang dikaruniakan oleh Tuhan kepada manusia, keberadaannya sangat penting sekali, artinya tanah dipakai untuk tempat tinggal, untuk usaha, dan untuk kegiatan-kegiatan lain yang terkait dengan kehidupan.

Sebidang tanah yang dimiliki oleh seseorang atau suatu badan usaha, harus jelas batasnya, letaknya dan bukti kepemilikannya. Untuk menandai hal tersebut, maka tanah diberi hak yang melekat padanya oleh pemerintah yang dalam hal ini adalah Badan Pertanahan Nasional (BPN) sebagai bukti kuat kepemilikan.

\footnotetext{
* Dosen pada Jurusan Geodesi FTSP ITS

jsh Jurnal Sosial Humaniora, Vo. 2, No. 1, Juni 2009
} 
Ada berbagai jenis hak yang ada terkait dengan tanah, namun sebidang tanah hanya mempunyai satu jenis hak. Hak tersebut antara lain adalah Hak Milik, Hak Guna Usaha, Hak Guna Bangunan ataupun Hak Pakai.

Dengan adanya hak tersebut, maka akan jelas siapa pemilik tanah, dimana letak tanah, berapa luas tanah dan sejenisnya yang tertuang dalam sertifikat.

Kepemilikan tanah dapat beralih dari satu pihak ke pihak lainnya dengan cara misalnya jual beli, hibah, wris dan sebgainya.

Harga tanah dari waktu ke waktu cenderung untuk terus naik, khususnya di daerah perkotaan yang mempunyai posisi strategis, juga untuk tanah-tanah yang subur. Oleh karena itu perasaan "memiliki” terhadap tanah akan semakin tinggi dan terkadang sangat berlebihan.

Dengan melihat peluang tanah yang harganya semakin hari semakin tinggi, maka ada beberapa pihak yang memanfaatkan tanah sebagai investasi ataupun tabungan. Tanah dikuasi ataupun dibeli, lalu dibiarkan tidak diurusi, hanya sebagai tabungan. Dengan berjalannya waktu, maka tanah tersebut tidak akan turun harganya. Tanah yang dibiarkan inilah yang disebut dengan tanah terlantar.

Hal ini tidak dibenarkan, karena tanah mempunyai fungsi sosial, artinya tanah tersebut seharusnya bisa digunakan untuk pihak lain, baik untuk tempat tinggal, tempat usaha dan sebagainya.

Tanah yang dibiarkan tidak terurus atau terlantar atau ditelantarkan (sebagai investasi) tentu akan merugikan berbagai pihak antara lain pemerintah (yang seharusnya dapat menarik pajak yang lebih besar apa bila tanah difungsikan dengan benar), orang yang seharusnya bisa memperoleh tanah menjadi terhalang, dan juga tanah akan "rusak", dalam arti kesuburannya dan kemanfaatannya.

Dalam peraturan pemerintah, tanah yang ditelantarkan oleh pemiliknya dapat dikuasi oleh Negara (lihat : PERATURAN PEMERINTAH (PP) REPUBLIK INDONESIA NOMOR 36 TAHUN 1998 TENTANG PENERTIBAN DAN PENDAYAGUNAAN TANAH TERLANTAR), pasal 15 
ayat (1) Tanah yang sudah dinyatakan sebagai tanah terlantar menjadi tanah yang dikuasai langsung oleh Negara.

Ruang lingkup tanah terlantar yang berada di Indonesia dengan berbagai jenis hak yang melekat pada tanah tersebut, misalnya Tanah Hak Milik, Hak Guna Usaha, Hak Guna Bangunan ataupun Hak Pakai. Tanah.

Tujuan penulisan ini adalah untuk mengetahui seberapa bayak tanah terlantar atau yang ditelantarkan dan kaitannya dengan Peraturan Pemerintah tentang tanah terlantar atau yang lebih tepat ditelantarkan.

Metoda yang digunakan adalah dengan menggunakan data sekunder dari bahan-bahan pustaka dan data primer yang berupa pengambilan gambar atau foto di lapangan yang berada di lapangan.

Pengumpulan data sekunder dilakukan untuk mendukung aturan yang telah ditetapkan oleh pemerintah, sedangkan data primer untuk memberi ilustrasi adanya taah terlantar.

Pengolahan data dilakukan dengan pentabelan yang selanjutnya dianalisis, dan tahap penutup berupa simpulan hasil penulisan.

\section{Kriteria Tanah Terlantar}

Tanah terlantar tentu ada penyebabnya, misalnya terlantar karena tidak mampu untuk membiayai tanah tersebut, yaitu untuk mendirikan bangunan atau memanfaatkan tanah tersebut. Ada kemungkinan lain yaitu sadar disengaja, jadi lebih tepatnya tanah ditelantarkan. Walaupun pemilik tetap membayar pajak atas tanah tersebut dan juga bangunannya, maka tanah yang terlantar tersebut tetap menyalahi fungsi sosial dari tanah yang seharusnya dapat dimanfaatkan untuk keperluan orang banyak dan untuk kehidupan.

Ada beberapa kriteria tanah terlantar menurut $\quad$ PP No. 36 Tahun 1998 Tentang Penertiban dan Pendayagunaan Tanah Terlantar), yaitu :

Tanah Hak Milik, Hak Guna Usaha, Hak Guna Bangunan atau Hak Pakai dapat dinyatakan sebagai tanah terlantar apabila tanah tersebut dengan sengaja tidak 
dipergunakan oleh pemegang haknya sesuai dengan keadaannya atau sifat dan tujuan haknya atau tidak dipelihara dengan baik.( Pasal 3)

Sebagai contoh, pembebasan tanah yang diperuntukkan perumahan, setelah tanah dibebaskan dan ijin untuk memulai pembangunan perumahannya sudah ada, daearah tersebut dibiarkan saja tidak segera dilakukan pembangunan atau pengadaan rumahnya. Dengan dibiarkan saja, maka harga tanah akan cenderung untuk naik terus sesuai dengan berjalannya waktu. Hal ini yang menyebabkan tanah terlantar.

Pasal 4 pada PP tersebut menjelaskan tentang Hak Milik, Hak Guna Bangunan dan Hak Pakai yang tidak dimaksudkan untuk dipecah, yaitu :

Tanah Hak Milik, Hak Guna Bangunan atau Hak Pakai yang tidak dimaksudkan untuk dipecah menjadi beberapa bidang tanah dalam rangka penggunaannya tidak dipergunakan sesuai dengan keadaannya atau sifat dan tujuan haknya sebagaimana dimaksud dalam Pasal 3, apabila tanah tersebut tidak dipergunakan sesuai dengan peruntukannya menurut Rencana Tata Ruang Wilayah yang berlaku pada waktu permulaan penggunaan atau pembangunan fisik di atas tanah tersebut.

Pada pasal 5 PP tersebut dijelaskan tentang Hak guna Usaha yang ditelantarkan yaitu apabila memenuhi criteria sebagai berikut

(1) Tanah Hak Guna Usaha tidak dipergunakan sesuai dengan keadaannya atau sifat dan tujuan haknya sebagaimana dimaksud dalam Pasal 3, apabila tanah itu tidak diusahakan sesuai dengan kriteria pengusahaan tanah pertanian yang baik sesuai dengan ketentuan peraturan perundang-undangan yang berlaku.

(2) Jika hanya sebagian dari bidang tanah Hak Guna Usaha sebagaimana dimaksud pada ayat (1) memenuhi kriteria terlantar, maka hanya bagian tanah tersebut yang dapat dinyatakan terlantar.

Selanjutnya dalam pasal 6 dijelaskan tentang Hak Guna Bangunan dan Hak Pakai yang termasuk dalam tanah terlantar, yaitu

(1) Tanah Hak Guna Bangunan atau Hak Pakai yang dimaksudkan untuk dipecah menjadi beberapa bidang tanah dalam rangka penggunaannya tidak dipergunakan sesuai dengan keadaannya atau sifat dan tujuan haknya sebagaimana dimaksud dalam Pasal 3, apabila tanah tersebut tidak dipecah dalam rangka pengembangannya sesuai dengan rencana kerja yang telah disetujui oleh instansi yang berwenang. 
(2) Jika hanya sebagian dari bidang tanah Hak Guna Bangunan atau Hak Pakai sebagaimana dimaksud pada ayat (1) memenuhi kriteria terlantar, maka hanya bagian bidang tanah tersebut yang dapat dinyatakan terlantar.

Untuk tanah dengan hak pengelolaan, yang dimaksud dengan terlantar adalah bial kewenangan hak menguasai dari Negara tidak dilaksanakan oleh pemegang hak pengelolaan seperti yang dijelaskan pada pasal 7 berikut ini.

(1) Tanah Hak Pengelolaan dapat dinyatakan sebagai tanah terlantar, apabila kewenangan hak menguasai dari Negara atas tanah tersebut tidak dilaksanakan oleh pemegang Hak Pengelolaan sesuai tujuan pemberian pelimpahan kewenangan tersebut.

(2) Jika hanya sebagian dari bidang tanah Hak Pengelolaan sebagaimana dimaksud pada ayat (1) yang memenuhi kriteria terlantar, maka hanya bagian bidang tanah tersebut yang dapat dinyatakan terlantar.

Selanjutnya pada pasal 8 dijelaskan sebagai berikut :

(1) Tanah yang sudah diperoleh penguasaannya, tetapi belum diperoleh hak atas tanah sesuai ketentuan peraturan perundang-undangan yang berlaku dapat dinyatakan sebagai tanah terlantar, apabila tanah tersebut oleh pihak yang telah memperoleh dasar penguasaan tidak dimohon haknya atau tidak dipelihara dengan baik.( Pasal 8)

(2) Jika hanya sebagian dari bidang tanah yang sudah diperoleh dan dikuasai sebagaimana dimaksud pada ayat (1) yang memenuhi kriteria terlantar, maka hanya bagian bidang tanah tersebut yang dapat dinyatakan terlantar.

Jadi tanah yang ditelantarkan menurut jenis haknya cukup banyak yaitu Hak Milik, Hak Guna Usaha, Hak Guna Bangunan dan Hak Pakai. Untuk jumlah tanah terlantar dari berbagai jnis hak tersebut, seluruh Indonesia mencapai sekitar 8 (delapan) juta bidang seperti yang akan dijelaskan pada uraian berikut ini.

\section{Beberapa Tanah Terlantar Di Indonesia}

Wilayah Indonesia yang cukup luas ini terdiri beberapa bidang tanah ( ada istilah lain dari bidang yaitu persil, walaupun ada yang menyebut persil adalah bagian dari bidang. Namun demikian persil dan bidang dalam konteks ini adalah sama).

Berdasarkan hasil sidang kelompok musrenbangnas bulan Mei tahun 2008 diperkirakan adanya tanah yang terlantar di seluruh Indonesia dengan berbagai jenis hak adalah 8 (delapan) juta bidang. Jumlah ini agak sulit untuk diekivalenkan dengan berapa hektar (ha), karena tiap bidang luasannya tentu 
tidak sama. Untuk bidang atau persil tanah di kota-kota umumnya kecil, tetapi untuk persil-persil di desa yang berupa sawah, tegalan atau kebun dapat luas sekali untuk ukuran satu persilnya.

Sebagai gambaran lain tentang tanah yang terlantar adalah di propinsi Riau dengan jenis hak tanah adalah HGU (Hak Guna Usaha) sebesar 17.127 (tujuh belas ribu seratus dua puluh tujuh) ha dan pelepasan hutannya yang dijadikan HGU sebesar 18.650 (delapan belas juta enam ratus lima puluh) ha .

Untuk daerah di kota metropolitan, Jakarta Barat, terdapat tanah yang tidak jelas pemiliknya yaitu sebayak 1.500 (seribu lima ratus ) persil. Menurut laporan Ditjen Pajak, persil tersebut pajak bumi bangunannya dibayar, tetapi pemiliknya tidak jelas. Tanah ini disebut juga sebagai tanah yang ditelantarkan.

Lokasi tanah seperti di Jakarta Barat tersebut tentu sangat disayangkan, karena tidak dimanfaatkan dengan baik, dibiarkan. Ada kemungkinan hanya sebagai tabungan atau investasi.

Ada juga tanah yang diterlantarkan yang terkait dengan permohonan ijin usaha yang telah disetujui, tetapi tidak segera ditindaklanjuti susuai dengan permohonan ijinnya. Di Jawa Barat misalnya Dari 136.794 ha yang diberi izin lokasi untuk perumahan, ternyata pembebasannya baru sekitar 50\% . Jumlah yang $50 \%$ inipun tidak dibangun semuanya pada kenyataan di lapangan yaitu kurang dari 20\%. Masih di Jawa Barat sebagai contoh, darii 79 izin lokasi kawasan industri (27.543 ha) yang diberikan baru 51 lokasi yang dibebaskan, dan itupun yang sudah dibangun kurang dari $10 \%$.

Secara ringkas, penjelasan tentang contoh keadaan tanah yang ditelantarkan di Indonesia dapat dilihat pada Tabel 1 berikut ini. 
Tabel 1

Contoh Keadaan Tanah Yang Ditelantarkan Di Indonesia

\begin{tabular}{|c|c|c|c|}
\hline Lokasi & Jenis & $\begin{array}{l}\text { Luasan atau } \\
\text { jumlah bidang }\end{array}$ & Keteranagan/ Sumber \\
\hline $\begin{array}{l}\text { Seluruh } \\
\text { Indonesia }\end{array}$ & $\begin{array}{l}\text { Berbagai } \\
\text { jenis hak }\end{array}$ & $\begin{array}{l}\text { sekitar } 8 \text { juta } \\
\text { bidang ,yang } \\
\text { perlu } \\
\text { diidentifikasi } \\
\text { lokasi. }\end{array}$ & $\begin{array}{l}\text { http://musrenbangnas.bappenas.go.id. } \\
\text { Dikunjungi 21/10/2008 jam 16.31 } \\
\text { RINGKASAN SIDANG KELOMPOK } \\
\text { MUSRENBANGNAS TAHUN } 2008 \\
\text { DALAM RANGKA PENYUSUNAN } \\
\text { RKP 2009 Kelompok : IB Wilayah D } \\
\text { (Sulawesi Utara, Gorontalo, Sulawesi } \\
\text { Tengah, Sulawesi Tenggara, Sulawesi } \\
\text { Barat, Sulawesi Selatan) Hari/ Tanggal } \\
\text { : Kamis/8 Mei 2008 Sesi pada jam : } \\
09.00-12.30\end{array}$ \\
\hline $\begin{array}{l}\text { Propinsi } \\
\text { Riau saat } \\
\text { ini }\end{array}$ & $\begin{array}{l}\text { HGU (Hak } \\
\text { Guna } \\
\text { Usaha) } \\
\text { Pelepasan } \\
\text { hutan }\end{array}$ & 18.650 ha & $\begin{array}{l}\text { Said Didu, http://kapanlagi.com. } \\
\text { Dikunjungi } 21 / 10 / 2008 \text { jam } 16.31\end{array}$ \\
\hline $\begin{array}{l}\text { Jakarta } \\
\text { Barat }\end{array}$ & - & $\begin{array}{l}1.500 \text { persil tanah } \\
\text { yang tidak jelas } \\
\text { pemiliknya } \\
\text { (terlantar) }\end{array}$ & $\begin{array}{l}\text { John MacDougall, Penertiban Tanah } \\
\text { Terlantar : apakabar@clark.net Sun } \\
\text { oct } 30 \text { 1994, Dikunjungi pada } \\
\text { 19/9/2008 jam 10:47 } \\
\text { (Berdasar laporan Ditjen Pajak) }\end{array}$ \\
\hline $\begin{array}{l}\text { Di Jawa } \\
\text { Barat }\end{array}$ & & $\begin{array}{l}\text { Dari } 136.794 \text { ha } \\
\text { yang diberi izin } \\
\text { lokasi untuk } \\
\text { perumahan, } \\
\text { ternyata } \\
\text { pembebasannya } \\
\text { baru sekitar 50\%, } \\
\text { sedang yang } \\
\text { dibangun kurang } \\
\text { dari } 20 \% \text {. } \\
\text { Dari } 79 \text { izin } \\
\text { lokasi kawasan } \\
\text { industri (27.543 } \\
\text { ha) yang } \\
\text { diberikan baru } 51 \\
\text { lokasi yang } \\
\text { dibebaskan, dan } \\
\text { yang sudah } \\
\text { dibangun kurang } \\
\text { dari } 10 \%\end{array}$ & $\begin{array}{l}\text { John MacDougall, Penertiban Tanah } \\
\text { Terlantar : apakabar@clark.net Sun } \\
\text { oct } 30 \text { 1994, Dikunjungi pada } \\
\text { 19/9/2008 jam 10:47 }\end{array}$ \\
\hline
\end{tabular}


Sebagai tambahan untuk tanah yang ditelantarkan, berikut ini ada ilustrasi bangunan dan tanah di wilayah Surabaya yang telah lama (lebih dari 15 tahun) dibiarkan, ditelantarkan, dibiarkan rusak tidak terurus. Padahal letak bangunan ini cukup strategis, gambar 1 dan 2

Penyebab ditelantarkan tanah dan bangunan ini karena unsur ketidakmampuan financial pemilik atau sebab lain.

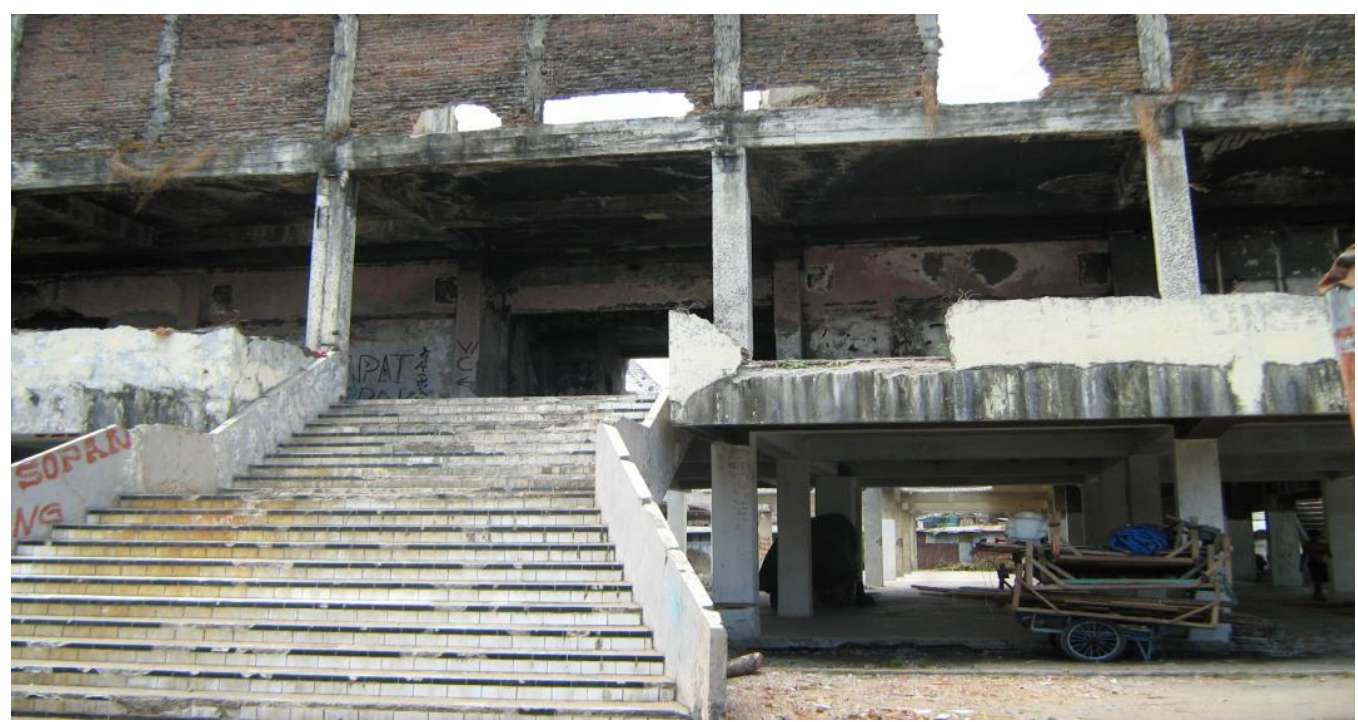

\section{Gambar 1}

Contoh Tanah dan Bangunan Yang Telantar (Lokasi Surabaya)

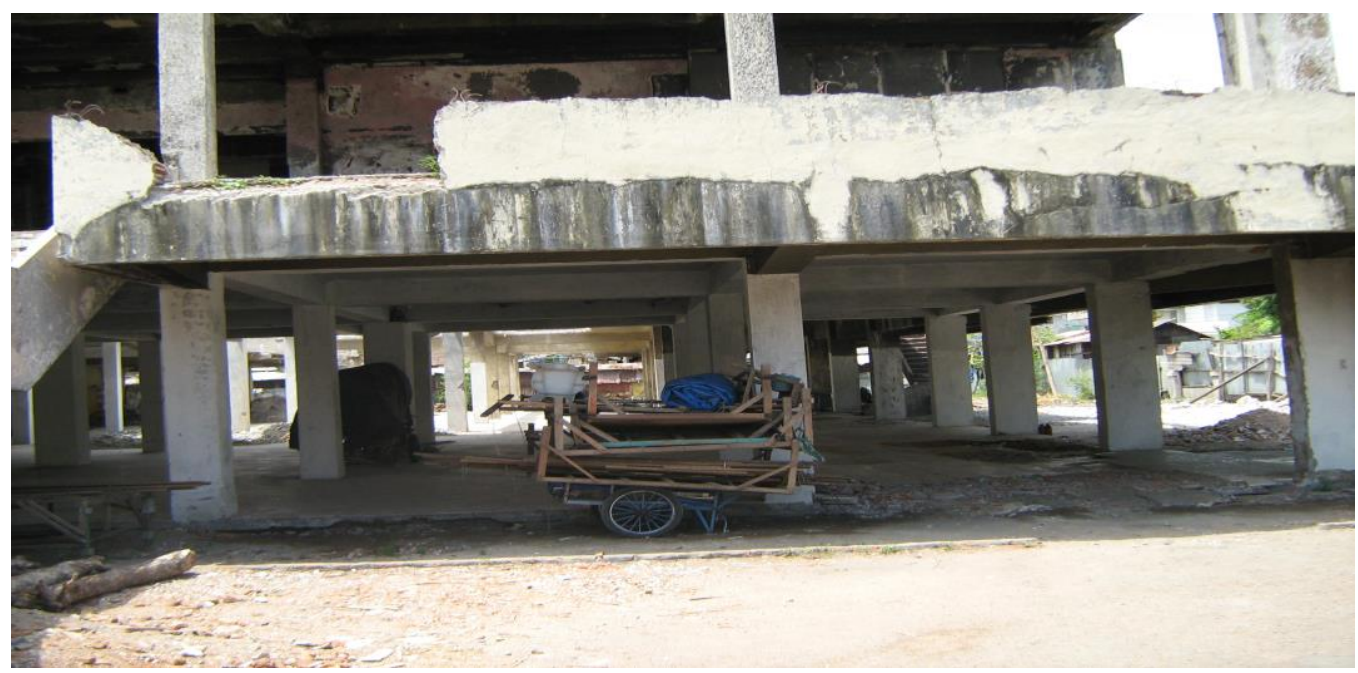

Gambar 2

Contoh Tanah dan Bangunan Yang Telantar (Lokasi Surabaya), foto dari sisi lain 


\section{Jalan Pemecahan Adanya Tanah Terlantar}

Akibat adanya tanah terlantar, maka banyak pihak yang dirugikan. Tanah tersebut tidak digunakan sebagaimana mestinya, banyak orang per-orang yang seharusnya bisa memanfaatkannya menjadi terhalang. Pemerintah yang seharusnya mendapatkan pemasukan dari manfaat tanah tersebut, misalnya dari pajak, akan terhambat juga.

Oleh karena itu pemerintah telah mengeluar Peraturan Pemerintah (PP)

Dalam Pearaturan Pemerintah (PP) No. 36 Tahun 1998 Tentang Penertiban dan Pendayagunaan Tanah Terlantar), pada prinsipnya antara lain adalah Negara menguasai tanah tersebut, dengan mengganti rugi sesuai dengan Ketetapan Menteri dan tidak merugikan bagi pemiliknya. Hal ini tertuang pada pasal 15 PP tersebut, yang berbunyi :

\section{Pasal 15}

(1) Tanah yang sudah dinyatakan sebagai tanah terlantar menjadi tanah yang dikuasai langsung oleh Negara.

(2) Kepada bekas pemegang hak atau pihak yang sudah memperoleh dasar penguasaan atas tanah yang kemudian dinyatakan sebagai tanah terlantar diberikan ganti rugi sebesar harga perolehan yang berdasarkan bukti-bukti tertulis yang ada telah dibayar oleh yang bersangkutan untuk memperoleh hak atau dasar penguasaan atas tanah tersebut yang jumlahnya ditetapkan oleh Menteri.

(3) Dalam hal pemegang hak atau pihak yang telah memperoleh dasar penguasaan atas tanah tersebut telah mengeluarkan biaya untuk membuat prasarana fisik atau bangunan di atas tanah yang dinyatakan terlantar, maka jumlah yang telah dikeluarkan tersebut diperhatikan dalam penetapan ganti rugi sebagaimana dimaksud pada ayat (2).

(4) Ganti rugi sebagaimana dimaksud pada ayat (2) dibebankan pada pihak yang oleh Menteri ditetapkan sebagai pemegang hak yang baru atas tanah tersebut.

Ada bentuk usulan pemecahan lain tentang tanah terlantar yaitu meniru model yang diterapkan oleh Gubernur Daerah istimewa Jogjakarta yaitu memanfaatkan tanah-tanah terlantar atau tanah tidur (Sitorus, Oloan , 2006). Modifikasi dan improvisasi dari semangat reforma agraria inilah yang mungkin diistilahkan oleh Gub DI Jogjakarta Sri Sultan Hamengku Buwono X, sebagi land 
reform "gaya baru", seperti mengijinkan pemakaian tanah terlantar atau lahan tidur untuk ditanami sayuran yang panennya setiap 30 hari atau pemanfaatan tanah hanya pada malam hari untuk berjualan makanan dan minuman )

Usulan lebih ekstrim untuk mencabut hak-hak yang telah diberikan sehubungan dengan tanah yang ditelantarkan (Said Didu, 2008). Ada pula yang mengusulkan tanpa ganti rugi.

Usulan penulis adalah penerapan pajak progresif terhadap tanah-tanah yang terlantar, hal ini belum diterapkan, namun demikian penerapan pajak progresip ini akan mendorong orang-perorang atau badan untuk segera memberdayakan tanah-tanah tersebut.

Pajak progresif adalah pajak yang besarnya meningkat dari nilai pajak yang normal, misalnya untuk contoh pembanding saja, apabilla mempunyai sepeda motor satu pajaknya " X" rupiah, maka sepeda motor ke dua, ketiga dan seterusnya yang dimilik orang tersebut, pajak tersebut tidak sama, yaitu lebih besar besar untuk yang kedua, yang ketiga lebih besar lagi dan seterusnya. Namun demikian besarnya pertambahan progresip tersebut, misalnya apakah $10 \%, 20 \%$ dan seterusnya , perlu adanya kajian yang lebih mendalam.

Untuk tanah terlantar, mungkin tanah progresif dapat dihitung berdasarkan luas tanahnya atau jenis haknya atau posisi (letak) tanah tersebut, atau kombinasi dari parameter tersebut.

\section{Kesimpulan}

Sebagai penutup, ternyata di Indonesia cukup banyak tanah yang terlantar atau yang ditelantarkan. Dalam bentuk lain tanah tersebut diistilahkan dengan tanah tidur. Tanah ditelantarkan ini selain merugikan pemerintah, juga menyalahi fungsi sosial dari tanah tersebut, karena tanah yang dibiarkan tidak terurus dan ditelantarkan seharusnya dapat digunakan bagi banyak orang yang membutuhkan, baik sebagai tempat tinggal maupun tempat usaha. 
Sebelum tanah terlantar dikuasai kembali oleh Negara, maka langkah yang dapat ditempuh adalah menerapkan pajak progresip bagi tanah yang terlantar,yaitu menaikan pajak untuk tanah-tanah yang terlantar. Perlu adanya inventarisasi yang lebih menyeluruh tentang letak-letak atau posisi tanah-tanah terlantar baik dari segi jenis haknya maupun luasannya.

\section{Daftar Pustaka}

John MacDougall, Penertiban Tanah Terlantar : apakabar@clark.net Sun oct 30 1994, Dikunjungi pada 19/9/2008 jam 10:47

PERATURAN PEMERINTAH REPUBLIK INDONESIA NOMOR 36 TAHUN 1998 TENTANG PENERTIBAN DAN PENDAYAGUNAAN TANAH TERLANTAR

Sitorus, Oloan . Reforma Agraria dan Sektor Informal (http://nasih.staff.ugm.ac.id), Monday, 25 September 2006. Dikunjungi pada 19/9/2008 jam 10:48

Undang-undang Dasar 1945 dan Amandemennya, penerbit ARKOLA.

http://musrenbangnas.bappenas.go.id. Dikunjungi 21/10/2008 jam 16.31 